\title{
About the Match of Trainees' Learning Styles to Their Tutors' Instructional Strategies and the Correlation of This Match with the Trainees' Academic Achievements
}

\author{
Hagit Krisher ${ }^{1} \&$ Nissim Sabag $^{2}$ \\ ${ }^{1}$ Support Center for Students with Special Needs, ORT Braude College, Karmiel, Israel \\ ${ }^{2}$ Department of Electrical and Electronic Engineering, ORT Braude College, Karmiel, Israel \\ Correspondence: Hagit Krisher, Support Center for Students with Special Needs, ORT Braude College, P.O. Box 78, \\ Karmiel 21982, Israel. Tel: 972-4-990-1909.
}

Received: January 12, 2017

Accepted: January 31, 2017

Online Published: February 27, 2017

doi:10.5430/irhe.v2n1p56

URL: http://dx.doi.org/10.5430/irhe.v2n1p56

\begin{abstract}
The match between students' learning styles $(L S)$ and their teachers' instructional strategies (IS) and the correlation of this LS-IS match with students' academic achievements was studied in earlier research. However, there is no report of research where one-on-one education is implemented. Moreover, there are no references relating the match of a trainees' $L S$ to their tutors' $I S$ and the correlation of this $L S$ - $I S$ match with the trainees' achievements. Accordingly, the current paper presents a study designed to investigate the correlation between a trainees' achievements and the $L S$-IS match. Two different methods were used to measure the $L S$ - $I S$ match. First, calculating the correlation between trainees' $L S$ and tutors' IS (LS-IS correlation); second, calculating the LS-IS distance. Forty-two trainees with learning disabilities were paired with 39 tutors (three tutors had two trainees each) during the 2016 academic year. Thus, 42 pairs of trainees and tutors worked to help the trainees achieve better academic grades. The Felder-Soloman Index of Learning Styles $(I L S)$ was used to measure the trainees' preferred $L S$ and the tutors' preferred $I S$. In the first method, the $L S$-IS correlations were correlated with the trainees' grades; then, in the second method, the $L S-I S$ distances were correlated with trainees' grades. If the $L S$ - IS match influences the trainees' achievements, significant positive correlations in the first method and significant negative correlation in the second method must appear. However, the results show no significant correlation (positive or negative, accordingly) between the LS-IS match and students' achievements at the end of the first semester of 2016. A replication of the above study was made in the second semester of 2016 and similar results were obtained.
\end{abstract}

Keywords: learning styles, instructional strategies, learning disabilities, tutor

\section{Introduction}

During the last two decades, one of the leading engineering colleges in Israel has been running a special program to help students with learning disabilities. Among other means, the program provides peer tutoring that was suggested by many researchers as a useful tool to improve academic achievements (Bowman-Perrott, Davis, Vannest, Williams, Greenwood, \& Parker, 2013; Okilwa \& Shelby, 2010). Students with learning disabilities are paired (as trainees) with excellent students who are strictly selected and trained to serve as tutors, and work together during two semesters to improve the trainees' academic achievements.

Much has been written on the relationship between the match of learning styles to instructional strategies (LS-IS match) and students' achievements (Safe, 2008; Tella, Tella, \& Adeniyi, 2009; Gilakjani, 2012). Therefore, the authors of the current paper thought it interesting to investigate the relationship between the match of trainees' learning styles to the tutors' instructional strategies ( $L S-I S$ match) and the trainees' academic achievements. Accordingly, the current study designed to investigate whether a good LS-IS match influences trainees' achievements.

The paper is organized as follows: Section 2 provides a theoretical review on peer tutoring; definitions of learning styles and models of learning styles followed by the Felder-Soloman Index of Learning Styles (ILS) and its validity and reliability; and learning styles and academic achievement. Section 3 presents the research question, the research 
method, and the research setting. In Section 4, the findings are described. In Sections 5 and 6, the findings are further discussed, conclusions presented, and future research directions suggested.

\section{Literature Review}

\subsection{Peer Tutoring}

The positive effects of peer tutoring have been demonstrated across much research over the last 40 years. The success of peer tutoring for both tutors and tutees is likely from incorporating instructional features such as frequent opportunities to respond, increased time on task, and regular and immediate feedback. Each of these components is empirically linked to increased academic achievement (Bowman-Perrott, Davis, Vannest, Williams, Greenwood, \& Parker, 2013). Peer tutoring is a commonly provided support service for trainees with learning disabilities $(L D)$ in institutions of higher education. The positive effects of peer tutoring have been demonstrated across subjects such as reading, math, and science (Guild \& Garger, 1985). In addition, peer tutoring is effective for trainees with and without disabilities, native English-speaking students, and English language learners (Okilwa \& Shelby, 2010). The positive effects of peer tutoring have been demonstrated across subjects such as reading (Oddo, Barnett, Hawkins, \& Musti-Rao, 2010), math (Hawkins, Musti-Rao, Hughes, Berry, \& McGuire, 2009), social studies (Lo \& Cartledge, 2004), and science (Bowman-Perrott, Greenwood, \& Tapia, 2007). Findings suggest that peer tutoring is an effective intervention, regardless of dosage, grade level, or disability status. Among students with disabilities, those with emotional and behavioral disorders benefitted most (Bowman-Perrott, Davis, Vannest, Williams, Greenwood, \& Parker, 2013). However, there are no references relating trainees' learning styles to their tutors' instructional strategies. Therefore, in this research, we investigated whether a good match between trainees learning styles to their tutors' instructional strategies (LS-IS match) influences trainees' achievements.

\subsection{Definition of Learning Style and Models of Learning Style}

Learning styles can be defined, classified, and identified in many different ways. They can also be described as a set of factors, behaviors, and attitudes that enhance learning in any situation. How the students learn and how the teachers teach, and how the two interact with each other, are influenced by different learning styles (Chermahini, Ghanbari \& Talab, 2013). Within the last three decades, the proposition that students learn and study in different ways has emerged as a prominent pedagogical issue. Learning styles (Coffield, Moseley, Hall, \& Ecclestone, 2004) and learning style models (Gregorc, 1979, 1985; Kolb, 1984; Felder \& Silverman, 1988; Dunn, Dunn, \& Price, 1989; Fleming, 2001; Duff, 2004) have offered descriptive typologies. Researchers have developed a vast array of models and instruments in an attempt to understand and develop a framework that explains how students learn. Coffield et al. (2004) have extensively reviewed the learning styles literature, evaluated the major learning styles models, and discussed the implications for practice. They identified 71 learning models and instruments and categorized 13 of them as major models. Hawk and Shah (2007) reviewed and compared five of the more commonly and recently used learning style models and instruments: the Kolb Learning Styles Indicator, Gregorc Style Delineator, Felder-Silverman Index of Learning Styles, VARK Questionnaire, and Dunn \& Dunn Productivity Environment Preference Survey. Their conclusion was that no one instrument can capture all the richness of the phenomenon of learning style. Kolb (1984) and Mumford and Honey (1992) describe learning style as an individual preferred or habitual way of processing and transforming knowledge. According to Kolb (1984), psychological attributes, resulting from individual differences, determine the particular strategies a person chooses while learning. Kolb and Boyatzis (1993) present four distinct learning styles (or preferences), which are based on a four-stage learning cycle: concrete experience, reflective observation, abstract conceptualization, and active experimentation.

\subsection{Index of Learning Styles (ILS)}

In 1988, Richard Felder and Linda Silverman developed a learning model that focuses specifically on aspects of learning styles of engineering students (Felder \& Silverman, 1988). The learning style model classifies students as having preferences for one category or the other in each of the following five dimensions: concrete/abstract, visual/auditory, inductive/deductive, active/reflective, and sequential/global. Later on the inductive/deductive dimension was omitted and the visual/auditory was replaced by the visual/verbal (Felder, 2002). The model posits that active students learn by trying things out and working with others; reflective students prefer to think things through and work alone; sensory students are practical and oriented toward facts and procedures; and intuitive students are conceptual, innovative, and oriented toward theories and meanings. Visual students prefer visual representations of material such as pictures, diagrams, or flow charts; verbal students prefer written and spoken explanations; sequential students tend to follow linear and orderly reasoning processes; and global students prefer to learn in intuitive leaps (Felder, 1993; Felder \& Silverman, 1988; Litzinger, Sang-Ha, Wise \& Felder, 2005). Lumsdaine and Lumsdaine (1995) concluded that the lack of congruence between preferred learning style and the 
nature of the subject matter and the method of teaching related to comparatively lower motivation and poorer performance, and hence possible failure to complete a course.

For this study, we elected to use the Felder-Soloman model and Index of Learning Styles (ILS) (Soloman \& Felder, 2014), which is an improvement of the Felder-Silverman model (Felder, 2002), because it is an instrument with a significant amount of study and use. Felder and Soloman developed this model in an engineering education environment that was relevant to our college's students. Many researchers relate to the validity and reliability of the Felder-Soloman Index of Learning Styles (Boyle, Duffy, \& Dunleavy, 2003; Hlawaty, 2002; Felder \& Spurlin, 2005; Litzinger et al., 2005; Zywno, 2003). Zywno uses 557 questionnaires for her Cronbach alpha analysis that resulted in Cronbach alphas between 0.53 and 0.70 for the four $L S$ dimensions, whereas alpha $>0.5$ is acceptable for attitude assessment. She also points out that three of the four dimensions are orthogonal and there is a small correlation between the sensing/intuitive and the sequential/global dimensions (Zywno, 2003). The Index of Learning Styles (ILS - Felder and Soloman, 2014) was "designed to capture the most important learning style differences among engineering students and provide a good basis for engineering instructors. The model shares commonalities with other popular learning style approaches, e.g., the Learning Style Inventory (LSI - Kolb, 1984) or the Myers-Briggs Type Indicator (MBTI; Lawrence, 1984). The ILS is explicitly said to not include 'either-or categories' of its bipolar dimensions. All scales are to be understood as continua, which means that a student's cognitive preference to learning on a given $I L S$ scale may be either fairly well balanced, moderately, or strongly distinctive for one or the other pole of the scale. The four bipolar ILS dimensions can be described as follows (Felder and Soloman, 2016):

1. Active - Reflective: Active learners tend to gather and understand information best if they engage with it actively and try things out, e.g., by debating, bringing something to application, or via teaching back. Reflective learners prefer to think about new things for themselves first and learn by thinking things through. The motto of active learners is "Let us try and see how it works", whilst reflective learners pursue the principle "Let me first think carefully about it".

2. Sensual - Intuitive: Sensing learners tend to do well when learning facts, and follow established approaches and procedures when solving problems. They are more goal-oriented, progress carefully and patiently, but avoid complex issues or surprises. Intuitive learners on the other hand prefer to explore different possibilities, relationships, and innovative approaches. They can better grasp new concepts, work usually faster and more innovatively, and have less difficulty with abstract concepts and mathematical expressions. However, they tend to avoid rote learning, repetition, routines, and fixed schemes.

3. Visual - Verbal: Visual learners remember more of what they have seen; for example, in pictures, diagrams, flow charts, films, and demonstrations. Instead, verbal learners prefer linguistically based learning that is written, and spoken information or declarations.

4. Sequential - Global: Sequential learners tend to understand better by learning in logical linear steps, where each step is the logical consequence of the previous step. In contrast, global learners rather tend to make big steps and gather different material and information quasi-randomly and without the recognition of contexts and relationships, but suddenly, they understand the whole context.

The ILS consists of 44 statements, 11 for each dimension. The respondent can choose 'a' or ' $b$ ', depending how each reflects his or her preference for each statement. For example, for the statement "I understand something after I"..., an active learner would mark ' $a$ - try it out' and a reflective learner would mark 'b - think it through' (Soloman \& Felder, 2014). Every ' $a$ ' response counts as +1 whereas a ' $b$ ' response counts as -1 ; this scoring method dictates the range of -11 to +11 for each dimension (Felder \& Spurlin, 2005; Litzinger et al., 2005; Graf, Viola, Leo, \& Kinshuk, 2007).

\subsection{Learning Styles and Academic Achievements}

Various scholars have defined learning style mostly as a signal for individual differences. These differences may manifest themselves in 'life styles' and even in personality types (Zhang \& Sternberg 2005). Different individuals use different learning styles and the effectiveneness of the learning style also varies among individuals (Warn, 2009). Several recent researchers claim that students' academic achievement is influenced by their learning styles (Gilakjani, 2012). Gilakjani (2012) argues that teachers should make every effort to match their instructional strategies to the student's learning style. He also claims that matching between a student's learning style and the teacher's instructional strategies ( $L S-I S$ match) could produce statistically significant improvements in the students' grades (Gilakjani, 2012). On the other hand, other research showed that learning style had no significant impact on 
achievement (Marrison \& Frick, 1994). Boyle, Duffy, and Dunleavy (2003) examined the relationship between learning style and academic performance and found moderate negative correlations between learning style and grade point average. They suggest that the $I L S$ has a rather limited role to play in predicting academic outcome and that $I L S$ may have a more useful diagnostic role to play in higher education, for early-stage detection of learners with inappropriate orientations to learning, who fail to adopt systematic processing strategies and consequently are in danger of failing to achieve the maximum benefit from their time in higher education (Boyle, Duffy, and Dunleavy, 2003).

It should be noted that these researchers examined the impact of specific learning styles on academic achievement and none of them demonstrated that matching a student's learning style to the teacher's instructional strategies is positively associated with academic performance. Furthermore, Brown et al. (2006) found no significant differences in performance between matched and mismatched students. In addition, Graf and Kinshuk (2007) analyzed the students' performance and behavior in the course, and found that students who learned from a course that matches their learning styles spent significantly less time in the course and achieved on average the same marks as students in a course that either mismatched their learning styles or included all available learning styles.

Sabag and Trotskovsky developed a method to measure the distance of student's learning style to the teacher's instructional strategies (LS-IS distance) as one of the LS-IS match methods, and examined the relationship between the LS-IS distance and the students' achievements in three schools with 165 students who studied 17 courses with eight teachers. They conclude that there is no evidence to the claim that matching learning styles to instructional strategies affects the students' achievements.

Moreover, Felder suggests that the professors teach their students so that every student will be able to function with all learning style modes. In his words, "if professors teach exclusively in a manner that favors their students' less preferred learning style modes, the students' discomfort level may be great enough to interfere with their learning. On the other hand, if professors teach exclusively in their students' preferred modes, the students may not develop the mental dexterity they need to reach their potential for achievement in school and as professionals" [1996, p.18].

In general, there is rich data obtained from studies on learning styles; however, there are no references relating trainees' learning styles to their tutors' instructional strategies and examining their LS-IS match correlation with the trainees' academic achievements.

\section{Methodology}

\subsection{Research Question and Hypothesis}

The purpose of this current study is to resolve the following: Does a close $L S$ - $I S$ match between trainees' $L S$ to their tutors' IS improve trainees' achievements? There is disagreement about the contribution of LS-IS match to students' achievements in the literature; therefore, it is interesting to explore whether a good match between trainees' learning styles to their tutors' instructional strategies positively influences trainees' achievements.

\subsection{Research Population}

The research population comprised 42 trainees and their 39 tutors. They were organized in 42 trainee-tutor pairs, where three tutors had two trainees each. The response rate is 32 out of 42 teams (ten teams missed part of the information and are therefore not included in the calculations). The trainees are students with learning disabilities. The tutors are excellent students in their $2^{\text {nd }}-4^{\text {th }}$ years of study, who were selected through comprehensive interviews and had strict preparation before receiving authorization to serve as tutors. The trainee-tutor teams worked together during one academic year (two semesters) to improve the trainees' academic achievements.

\subsection{Learning Styles Questionnaire}

The Index of Learning Styles Questionnaire (ILS) (Soloman, \& Felder, 2014) was translated into Hebrew and validated using the following method. Four groups of 20-30 students, who are not part of the research population, answered the questionnaire successively and were asked to write comments about any unclear issue they encountered. All the comments from the first group were discussed and the appropriate adaptations were incorporated into the questionnaire. Thereafter, the second group filled in the questionnaire. This procedure was repeated until the Hebrew version of the questionnaire was fully clear to the fourth group. Internal consistency was checked by calculating Cronbach's alpha for each dimension. The results, shown in Table 1-which presents values of Cronbach's alpha for the research population - are in line with the literature (Felder \& Spurlin, 2005; Zywno, 2003). According to Tuckman (1999), an alpha of 0.50 or greater is acceptable for questionnaires that assess attitude and preference. As 
shown in Table 1, all the alpha values meet this criterion. Therefore, the internal consistency of the questionnaire is satisfied.

Table 1. Cronbach's alpha of each dimension in the $L S$ questionnaire

\begin{tabular}{ccccc}
\hline \multicolumn{1}{c}{ Dimension } & $\begin{array}{c}\text { Visual-Verbal } \\
(\mathbf{k}=\mathbf{4})\end{array}$ & $\begin{array}{c}\text { Sequential-Global } \\
(\mathbf{k}=\mathbf{3})\end{array}$ & $\begin{array}{c}\text { Sensing-Intuitive } \\
(\mathbf{k}=\mathbf{2})\end{array}$ & $\begin{array}{c}\text { Active-Reflective } \\
(\mathbf{k}=\mathbf{1})\end{array}$ \\
\hline Cronbach's alpha $(\mathrm{n}=165)$ & 0.6 & 0.5 & 0.6 & 0.5 \\
\hline
\end{tabular}

According to Gilakjani (2012), teachers teach the way they preferred to learn when they were students. Therefore it is reasonable to conclude the same with tutors and to use the same questionnaire for both trainees and for tutors. The tutors were asked to think of the way they guide while answering the questionnaire. For example, exchanging the word understand with explain makes the tutors' item (4) of the ILS, "I tend to" as either:

a. explain details of a subject but may be fuzzy about its overall structure.

or b. explain the overall structure but may be fuzzy about the details.

Based on Graf et al. (2007), Table 2 describes the items in the questionnaire associated with $L S$ dimensions.

Table 2. Questionnaire items associated with $L S$ dimensions

\begin{tabular}{lllll}
\hline $\mathbf{k}$ & Dimension & Items in the questionnaire & $\begin{array}{c}\text { ' } \boldsymbol{a} \text { ' } \\
\text { preference }\end{array}$ & 'b' preference \\
\hline 1 & Active-Reflective & $1,5,9,13,17,21,25,29,33,37,41$ & Active & Reflective \\
2 & Sensing-Intuitive & $2,6,10,14,18,22,26,30,34,38,42$ & Sensing & Intuitive \\
3 & Sequential-Global & $4,8,12,16,20,24,28,32,36,40,44$ & Sequential & Global \\
4 & Visual-Verbal & $3,7,11,15,19,23,27,31,35,39,43$ & Visual & Verbal \\
\hline
\end{tabular}

\subsection{Measuring Methods}

To examine the relationship between $L S-I S$ closeness and trainees' achievements, two methods were conducted. First, correlation between trainees' $L S$ and their tutors' $I S$ was calculated, then this $L S$-IS correlation was correlated to trainees' achievements. The second method is explained in detail in paragraph 3.4.1 below.

\subsubsection{Measuring LS-IS Correlations}

Correlations between the total tutor's $I S$ and the total trainee's $L S$ were calculated for each trainee-tutor pair. It was expected that a higher trainee-tutor correlation would yield higher trainee's achievements. However, there is a problem in calculating correlations for each individual $L S$ dimension; when one of the trainee-tutor pair is consistent in his or her choice for one dimension (e.g., one prefers ' $a$ ' for all the items of $k 4$ ), the correlation calculation results in $0 / 0$, which is not defined, and the measurement of this trainee-tutor pair must be eliminated. A lot of data is lost for this reason.

\subsubsection{Measuring LS-IS Distance}

The method of measuring LS-IS distance was first demonstrated in Sabag and Trotskovsky (2016). Following is a short explanation for the reader's convenience, using numbers updated to the current study.

The score of dimension $\mathrm{k}$ for trainee $\mathrm{i}$ is written as $L S_{i k}$ where $1 \leq k \leq 4$ and is calculated by summing all 'a' preferences and ' $\mathrm{b}$ ' preferences that are associated with dimension $\mathrm{k}$. Note that the total $L S$ of trainee $\mathrm{i}$ is $L S_{i}$ and is calculated using Equation (1).

$$
L S_{i}=\sum_{k=1}^{4} L S_{i k}
$$


In other words, $L S_{i}$ is the sum of the four dimensions' score for trainee i. $L S_{j}$ is defined similarly for tutor $\mathrm{j}$.

To define the $L S-I S$ distance, let $L S_{i k}$ be the score given by trainee i for dimension $\mathrm{k}$, and $I S_{j k}$ the score given

by tutor $\mathrm{j}$ for the corresponding dimension. The absolute difference $D_{i j k}=\left|L S_{i k}-I S_{j k}\right|$ is the distance between trainee $\mathrm{i}$ and tutor $\mathrm{j}$ for dimension $\mathrm{k}$. The total distance between trainee i's $L S_{i}$ and tutor j's $L S_{j}$ is the sum of all distances of the four dimensions, calculated by Equation (2):

$$
D_{i j}=\sum_{k=1}^{4}\left|L S_{i k}-I S_{j k}\right|
$$

For example: the $L S$ of trainee 8 for k1 (Active-Reflective) is 11 . The $I S$ of tutor 8 for $\mathrm{k} 1$ is 3 . Therefore, $L S_{8,1}=11 ; \quad I S_{8,1}=3$ and the distance between trainee 8 and tutor 8 for $\mathrm{k} 1$ is $D_{8,8,1}=|11-3|=8$.

The other measures for trainee 8 are $\mathrm{k} 2=11, \mathrm{k} 3=7$, and $\mathrm{k} 4=9$, so the total $L S_{8}=38$.

Similarly, for tutor 8 , the measures are $\mathrm{k} 2=3, \mathrm{k} 3=-3$, and $\mathrm{k} 4=7$, so the total is $I S_{8}=10$.

The total distance between trainee 8 and tutor 8 is $D_{8,8}=|38-10|=28$.

\section{Results}

The 32 teams of trainees and their tutors who participated in the research filled out the $L S$ and $I S$ questionnaires, respectively. The averages of all final grades in the first semester of 2016 and then again in the second semester of 2016 were calculated for each trainee. At the beginning, correlations between trainee's $L S$ and his or her tutor's $I S$ were calculated (LS-IS correlations) for each dimension and for the total LS-IS, for all trainee-tutor pairs. The blank spaces indicate cases where the correlation resulted in $0 / 0$ and was therefore eliminated. The results are depicted in Table 3. The last two rows present the correlations between LS-IS correlations and the trainees' achievements for each dimension and for the total $L S-I S$.

Table 3. Trainee-tutor LS-IS correlation and trainees' achievements

\begin{tabular}{|c|c|c|c|c|c|c|c|}
\hline \multirow[t]{2}{*}{ Pair no. } & \multicolumn{5}{|c|}{$\begin{array}{l}\text { LS-IS correlation for each dimension } \\
\text { and total }\end{array}$} & \multirow{2}{*}{$\begin{array}{l}\text { First semester } \\
\text { trainees' } \\
\text { average grades }\end{array}$} & \multirow{2}{*}{$\begin{array}{c}\text { Second } \\
\text { semester } \\
\text { trainees' } \\
\text { average grades }\end{array}$} \\
\hline & K1 & K2 & K3 & K4 & Total & & \\
\hline 1 & 0.19 & 0.52 & 0.26 & 0.15 & 0.09 & 76.4 & 84.5 \\
\hline 2 & 0.45 & 0.39 & 0.47 & & 0.38 & 70.9 & 62.0 \\
\hline 3 & 0.62 & -0.26 & -0.26 & 0.10 & 0.03 & 82.9 & 83.4 \\
\hline 4 & -0.46 & 0.45 & 0.26 & & 0.02 & 82.6 & 71.6 \\
\hline 5 & 0.21 & -0.29 & 0.24 & 0.36 & 0.12 & 73.5 & 71.5 \\
\hline 6 & 0.39 & & -0.15 & & 0.15 & 78.8 & 77.1 \\
\hline 7 & 0.04 & -0.39 & & 0.07 & 0.03 & 84.2 & 73.9 \\
\hline 8 & & & 0.36 & -0.15 & 0.16 & 79.3 & 89.3 \\
\hline 9 & -0.42 & 0.04 & 0.45 & 0.45 & 0.13 & 73.3 & 20.8 \\
\hline 10 & -0.61 & -0.29 & 0.21 & -0.15 & -0.18 & 79.0 & 80.7 \\
\hline 11 & & 0.15 & -0.07 & -0.22 & -0.12 & 85.1 & 84.9 \\
\hline
\end{tabular}




\begin{tabular}{cccccccc}
12 & -0.31 & -0.15 & 0.10 & 0.24 & -0.06 & 77.2 & 77.3 \\
13 & -0.13 & 0.29 & 0.29 & 0.31 & 0.17 & 80.6 & 66.6 \\
14 & 0.47 & -0.19 & 0.52 & 0.38 & 0.29 & 72.0 & 67.9 \\
15 & 0.15 & -0.22 & -0.45 & -0.10 & -0.06 & 79.9 & 77.3 \\
16 & -0.07 & -0.04 & -0.10 & -0.29 & -0.08 & 80.6 & 74.1 \\
17 & 0.24 & & -0.24 & & -0.03 & 88.0 & 77.3 \\
18 & -0.36 & 0.29 & 0.24 & -0.13 & 0.00 & 86.5 & 83.7 \\
19 & 0.81 & -0.19 & -0.04 & -0.04 & 0.32 & 71.2 & 40.6 \\
20 & & -0.19 & 0.45 & -0.24 & 0.05 & 86.7 & 91.2 \\
21 & -0.63 & 0.81 & 0.26 & & 0.06 & 75.3 & 80.6 \\
22 & -0.07 & 0.19 & 0.61 & 0.31 & 0.17 & 81.8 & 72.7 \\
23 & 0.04 & -0.24 & 0.08 & & -0.09 & 81.2 & 76.7 \\
24 & & 0.08 & -0.62 & 0.21 & -0.03 & 75.9 & 76.9 \\
25 & 0.21 & 0.13 & 0.52 & & 0.24 & 81.1 & 73.4 \\
26 & 0.26 & -0.36 & 0.31 & & 0.11 & 76.6 & 59.8 \\
27 & 0.24 & 0.21 & -0.15 & -0.21 & 0.04 & 82.9 & 65.7 \\
28 & 0.04 & -0.35 & -0.24 & -0.38 & -0.18 & 77.9 & 85.5 \\
29 & 0.04 & 0.13 & -0.24 & 0.42 & 0.26 & 63.6 & 61.0 \\
30 & -0.27 & -0.08 & -0.27 & 0.42 & -0.11 & 75.9 & 84.4 \\
31 & 0.07 & 0.57 & 0.46 & -0.19 & 0.26 & 78.8 & 69.8 \\
32 & 0.63 & 0.45 & 0.38 & -0.04 & 0.26 & 64.8 & 58.1 \\
Correlations with second & & & & & & & \\
semester grades & $\mathbf{- 0 . 1 9}$ & $\mathbf{- 0 . 0 4}$ & $\mathbf{- 0 . 2 1}$ & $\mathbf{- 0 . 3 8}$ & $\mathbf{- 0 . 5 2}$ & & \\
Correlations with first & & & $-\mathbf{0 . 0 7}$ & $\mathbf{- 0 . 4 7}$ & $\mathbf{- 0 . 5 3}$ & & \\
\hline
\end{tabular}

As shown in Table 3 there are significant negative correlations between LS-IS correlations and trainees' achievements, whereas positive correlations were expected.

The second method of examining the relationship between $L S$-IS closeness and trainees' achievements is to correlate $L S-I S$ distances and the trainees' achievements. For this, the $L S-I S$ distances were calculated for each trainee and his or her tutor. Correlations between $L S-I S$ distances and the trainees' achievements in the first semester of 2016 and then again in the second semester of 2016 were analyzed.

An example of the measured $L S_{1 \mathrm{~K}}$ for trainee 1 and $I S_{1 \mathrm{~K}}$ for his tutor (1), the total $L S_{1}$ and $I S_{1}$, the distances $D_{l, I, K}$ and $D_{l, l}$, as well as the trainee's (1) average grade for the first semester of 2016 are presented in Table 4.

Table 4. A detailed example of calculating $L S_{K}, I S_{K}$, and $L S$ - $I S$ distances for trainee 1 and tutor 1 and the trainee's average grades in first semester of 2016

\begin{tabular}{lccccccccccc}
\hline Participant & $\mathbf{k 1}$ & $\mathbf{k 2}$ & $\mathbf{k 3}$ & $\mathbf{k 4}$ & Total & $\mathbf{D}_{\mathbf{1 , 1}, \mathbf{1}}$ & $\mathbf{D}_{\mathbf{1 , 1 , 2}}$ & $\mathbf{D}_{\mathbf{1 , 1 , 3}}$ & $\mathbf{D}_{\mathbf{1 , 1 , 4}}$ & $\mathbf{D}_{\mathbf{1 , 1}}$ & Average \\
\hline Tutor 1 & -5 & 7 & 5 & -1 & 6 & & & & & & \\
Trainee 1 & 9 & 1 & 1 & 5 & 16 & 14 & 6 & 4 & 6 & 10 & 76.42 \\
\hline
\end{tabular}


The calculations of the LS-IS distances and their correlations with trainees' average grades for all tutors and their trainees appear in Table 5.

Table 5. Calculations of the $L S$-IS distances and the correlation with trainee's average grades

\begin{tabular}{|c|c|c|c|c|c|c|c|}
\hline \multirow[b]{2}{*}{$\begin{array}{l}\text { Trainee-Tutor } \\
\text { pair no. }\end{array}$} & \multicolumn{5}{|c|}{$\begin{array}{c}\text { Trainee-tutor distances for Ki dimension and } \\
\text { total }\end{array}$} & \multirow[b]{2}{*}{$\begin{array}{l}\text { First semester } \\
\text { average grades }\end{array}$} & \multirow[b]{2}{*}{$\begin{array}{c}\text { Second semester } \\
\text { average grades }\end{array}$} \\
\hline & K1 & K2 & K3 & K4 & Total & & \\
\hline 1 & 14 & 6 & 4 & 6 & 10 & 76.4 & 84.5 \\
\hline 2 & 2 & 2 & 2 & 10 & 12 & 70.9 & 62.0 \\
\hline 3 & 4 & 6 & 6 & 2 & 14 & 82.9 & 83.4 \\
\hline 4 & 2 & 2 & 4 & 14 & 22 & 82.6 & 71.6 \\
\hline 5 & 0 & 2 & 12 & 10 & 20 & 73.5 & 71.5 \\
\hline 6 & 2 & 2 & 4 & 6 & 10 & 78.8 & 77.1 \\
\hline 7 & 6 & 8 & 10 & 2 & 26 & 84.2 & 73.9 \\
\hline 8 & 8 & 8 & 10 & 2 & 28 & 79.3 & 89.3 \\
\hline 9 & 12 & 6 & 2 & 2 & 18 & 73.3 & 20.8 \\
\hline 10 & 6 & 8 & 0 & 4 & 18 & 79.0 & 80.7 \\
\hline 11 & 16 & 16 & 4 & 0 & 36 & 85.1 & 84.9 \\
\hline 12 & 2 & 4 & 2 & 12 & 16 & 77.2 & 77.3 \\
\hline 13 & 10 & 12 & 10 & 4 & 36 & 80.6 & 66.6 \\
\hline 14 & 2 & 4 & 4 & 10 & 0 & 72.0 & 67.9 \\
\hline 15 & 6 & 0 & 4 & 0 & 2 & 79.9 & 77.3 \\
\hline 16 & 4 & 8 & 0 & 2 & 10 & 80.6 & 74.1 \\
\hline 17 & 12 & 10 & 6 & 18 & 46 & 88.0 & 77.3 \\
\hline 18 & 4 & 10 & 2 & 10 & 2 & 86.5 & 83.7 \\
\hline 19 & 2 & 4 & 2 & 2 & 2 & 71.2 & 40.6 \\
\hline 20 & 16 & 4 & 2 & 6 & 20 & 86.7 & 91.2 \\
\hline 21 & 2 & 2 & 4 & 12 & 16 & 75.3 & 80.6 \\
\hline 22 & 4 & 14 & 0 & 4 & 14 & 81.8 & 72.7 \\
\hline 23 & 8 & 12 & 0 & 8 & 12 & 81.2 & 76.7 \\
\hline 24 & 10 & 0 & 10 & 0 & 20 & 75.9 & 76.9 \\
\hline 25 & 0 & 4 & 6 & 4 & 6 & 81.1 & 73.4 \\
\hline 26 & 4 & 4 & 4 & 6 & 10 & 76.6 & 59.8 \\
\hline 27 & 2 & 0 & 4 & 6 & 12 & 82.9 & 65.7 \\
\hline 28 & 8 & 10 & 12 & 0 & 30 & 77.9 & 85.5 \\
\hline 29 & 8 & 4 & 6 & 6 & 24 & 63.6 & 61.0 \\
\hline 30 & 2 & 10 & 2 & 6 & 0 & 75.9 & 84.4 \\
\hline 31 & 2 & 6 & 8 & 4 & 4 & 78.8 & 69.8 \\
\hline 32 & 0 & 2 & 10 & 8 & 4 & 64.8 & 58.1 \\
\hline $\begin{array}{l}\text { Correlations } \\
\text { with first } \\
\text { semester } \\
\text { grades }\end{array}$ & 0.32 & 0.42 & -0.15 & 0.01 & 0.32 & & \\
\hline $\begin{array}{l}\text { Correlations } \\
\text { with second } \\
\text { semester } \\
\text { grades }\end{array}$ & 0.17 & 0.24 & 0.09 & 0.05 & 0.18 & & \\
\hline
\end{tabular}

As shown in Table 5, there is no single $D_{j i k}$ or $D_{j i}$ with consistent significant negative correlations. 


\section{Discussion}

All the research, in the literature, concerning the LS-IS match and its correlation to students' achievements was done in the group context, i.e., one teacher and a group of students. Therefore, even if the findings show solid evidence proving that a good LS-IS match positively affects students' achievements, this still leaves the teacher with a big dilemma: to which style to adjust his or her teaching, since every group has many different $L S$. The current study suggests a unique opportunity in which the learning-teaching is a one-on-one situation. Therefore, it could be helpful to report the findings of such a case.

The Felder-Silberman ILS questionnaire, whose validation and reliability are well proven, measures the trainees' $L S$ and their tutors' $I S$. Moreover, the Hebrew version of the questionnaire was validated as explained in paragraph 3.3 and its consistency was calculated as depicted in Table 1. The LS-IS match was calculated in two methods. First, the $L S-I S$ correlation for every dimension (K1-K4) and for the total $L S-I S$ were calculated for each trainee-tutor pair; the results appear in Table 3. If the assumption is that a close $L S-I S$ match influences the trainees' achievements, then a significant positive correlation must appear between trainees' achievements and trainee-tutor LS-IS correlation. Table 3 reveals no such positive correlation. It means that there is no influence of the LS-IS match on the trainees' achievements (at least, no positive influence).

In the second method to examine the relationship between $L S$-IS match and trainees' achievements, the $L S$-IS distance (for every dimension and for the total) between each trainee and his or her tutor was calculated as explained in paragraph 3.4.2 above; the results are detailed in Table 5. Again, if the assumption is that a close LS-IS match influences the trainees' achievements, then a significant negative correlation must appear between trainees' achievements and trainee-tutor $L S-I S$ distance (i.e., the smaller the distance, the higher the achievement). The results in Table 5 show no significant negative correlation to support the assumption that a good LS-IS match has a good influence on trainees' achievements.

\section{Conclusion}

The current paper presents a study designed to investigate the correlation between trainees' achievements and the $L S$-IS match. There is no report of research where one-on-one education is implemented so it is a good opportunity to report on the described case. Although it should be noted that the tutors are not teachers; they do not teach a certain course, but meet their trainees for a few hours a week, every week, and help their trainees overcome learning obstacles. They have a meaningful influence on their trainees' learning, but their influence is not the only one; teachers of the different courses also have an impact on the trainees' achievements.

The findings of this study should be considered in light of the following limitations. One limitation is that the described study deals with engineering students; it is suggested to run similar research with different disciplines and different populations (e.g., humanities). Another recommendation is that future studies should apply the correlation of trainees' achievements with their attitudes toward peer tutoring and/or toward their own tutors. Future research should also examine the relation between academic and behavioral outcomes for students engaged in peer tutoring.

The results of the future studies suggested above might contribute to an understanding of the learning styles and instructional strategies of students in the context of one-on-one situations.

\section{References}

Bowman-Perrott, L., Davis, H., Vannest, K., Williams, L., Greenwood, C., \& Parker, R. (2013). Academic benefits of peer tutoring a meta-analytic review of single-case research. School Psychology Review, 42(1), 39-55.

Bowman-Perrott, L.J., Greenwood, C.R., \& Tapia, Y. (2007). The efficacy of peer tutoring used in secondary alternative school classrooms with small teacher/pupil ratios and students with emotional and behavioral disorders. Education and Treatment of Children, 30(3), 65-87. https://doi.org/10.1353/etc.2007.0014

Boyle, E. A., Duffy, T., \& Dunleavy, K. (2003). Learning styles and academic outcome: The validity and utility of Vermunt's Inventory of Learning Styles in a British higher education setting. British Journal of Educational Psychology, 73, 267-290. https://doi.org/10.1348/00070990360626976

Brown, E., Brailsford, T., Fisher, T., Moore, A., \& Ashman, H. (2006, May). Reappraising cognitive styles in adaptive web applications. In Proceedings of the 15th international conference on World Wide Web (pp. 327-335). ACM. https://doi.org/10.1145/1135777.1135827

Chermahini S.A., Ghanbari, A., \& Talab, M.G. (2013). Learning styles and academic performance of students in English as a second-Language class in Iran. Bulgarian Journal of Science and Education Policy, 7(2), 322. 
Coffield, F., Moseley, D., Hall, E., \& Ecclestone, K. (2004). Learning styles and pedagogy in post 16 learning: A systematic and critical review. The Learning and Skills Research Centre.

Duff, A. (2004). A note on the problem solving style questionnaire: An alternative to Kolb's learning style inventory?. Educational Psychology, 24(5), 699-709. https://doi.org/10.1080/0144341042000262999

Dunn, R.S., Dunn, K. J., \& Price, G.E. (1989). Learning style inventory (LSI). Price Systems, Incorporated.

Felder, R.M. (1993). Reaching the second tier - Learning and teaching styles in college science education. Journal of College Science Teaching, 22(5), 286-290.

Felder, R.M. (1996). Matters of style. AEEE Prism, December Issue, 18-23. Retrieved from http://www4.ncsu.edu/unity/lockers/users/f/felder/public/Papers/LS-Prism.htm

Felder, R.M. (2002). Author's preface to learning and teaching styles in engineering education. Retrieved from http://www4.ncsu.edu/unity/lockers/users/f/felder/public/Papers/LS-1988.pdf

Felder, R.M. (2010). Are learning styles invalid? (Hint: No!). On-Course Newsletter. 1-7. Retrieved from http://www4.ncsu.edu/unity/lockers/users/f/felder/public/Papers/LS_Validity(On-Course).pdf

Felder, R.M., \& Silverman, L.K. (1988). Learning and teaching styles in engineering education. Engineering Education, 78(7), 674-681.

Felder, R.M., \& Soloman, B.A. (2016). Learning Styles and Strategies. Retrieved September 25, 2016, from http://www4.ncsu.edu/unity/lockers/users/f/felder/public/ILSdir/styles.htm

Felder, R.M., \& Spurlin, J. (2005). Applications, reliability and validity of the Index of Learning Styles. International Journal of Engineering Education, 21(10), 103-112.

Fleming, N.D. (2001). Teaching and learning styles: VARK strategies. IGI Global.

Gilakjani, A.P. (2012). A match or mismatch between learning styles of the learners and teaching styles of the teachers. I. J. Modern Education and Computer Science, 11, 51-60. https://doi.org/10.5815/ijmecs.2012.11.05

Graf, S., \& Kinshuk, K. (2007). Providing Adaptive Courses in Learning Management Systems with Respect to Learning Styles. In T. Bastiaens \& S. Carliner (Eds.), Proceedings of E-Learn: World Conference on E-Learning in Corporate, Government, Healthcare, and Higher Education 2007 (pp. 2576-2583). Chesapeake, VA: Association for the Advancement of Computing in Education (AACE). Retrieved September 26, 2016, from https://www.learntechlib.org/p/26739

Graf, S., Viola, S.R., Leo, T., \& Kinshuk, K. (2007). In-depth analysis of the Felder-Silverman Learning Style Dimensions. Journal of Research on Technology in Education, 40(1), 79-93. https://doi.org/10.1080/15391523.2007.10782498

Gregorc, A.F. (1979). Learning-Teaching Styles-Potent Forces Behind Them. Educational Leadership, 36(4), 234-236.

Gregorc, A.F. (1985). Inside styles: beyond the basics: questions and answers on style. Gabriel Systems.

Guild, P.B., \& Garger, S. (1985). Marching to different drummers. Alexandria, VA: Association for Supervision and Curriculum Development.

Hawk, T.F., \& Shah, A.J. (2007). Using learning style instruments to enhance student learning, decision sciences. Journal of Innovative Education, 5(1), 1-19.

Hawkins, R.O., Musti-Rao, S., Hughes, C., Berry, L., \& McGuire, S. (2009). Applying a randomized interdependent group contingency component to classwide peer tutoring for multiplication fact fluency. Journal of Behavioral Education, 18, 300-318. https://doi.org/10.1007/s10864-009-9093-6

Hlawaty, H. (2002). Comparative Analysis of the Learning Styles of German Adolescents by Age, Gender, and Academic Achievements Level. (Report no. TM033774). Paper presented at the annual meeting of the American Educational Research Association, New Orleans, LA, April 2002. (ERIC NO. ED464094).

Kolb, D.A. (1984). Experiential learning: experience as the source of learning and development. Englewood Cliffs, New Jersey: Prentice Hall.

Kolb, D.A., \& Boyatzis, R.E. (1993). Learning Skills Profile. Boston: McBer and Company.

Lawrence, G. (1984). Synthesis of Learning Style Research Involving the MBTI. Journal of Psychological Type, 8 , $35-41$. 
Litzinger, T.A., Sang-Ha, L., Wise, J.C., \& Felder, R.M. (2005). A Study of the Reliability and Validity of the Felder-Soloman Index of Learning Styles. Proceedings of the 2005 American Society for Engineering Education Annual Conference \& Exposition, American Society for Engineering Education 2005.

Lo, Y.Y., \& Cartledge, G. (2004). Total class peer tutoring and interdependent group oriented contingency: Improving the academic and task related behaviors of fourth-grade urban students. Education and Treatment of Children, 235-262.

Lumsdaine, M., \& Lumsdaine, E. (1995). Thinking preferences of engineering students: Implications for curriculum $\begin{array}{llll}\text { restructuring. Journal of Engineering } & \text { Education, }\end{array}$ https://doi.org/10.1002/j.2168-9830.1995.tb00166.x

Marrison, D.L., \& Frick, M.J. (1994). The effect of agricultural students' learning styles on academic achievement and their perceptions of two methods of instruction. Journal of Agricultural Education, 35(1), 26-30. https://doi.org/10.5032/jae.1994.01026

Mumford, A., \& Honey, P. (1992). Questions and answers on learning styles questionnaire. Industrial and Commercial Training, 24(7), 10-13. https://doi.org/10.1108/00197859210015426

Oddo, M., Barnett, D.W., Hawkins, R.O., \& Musti-Rao, S. (2010). Reciprocal peer tutoring and repeated reading: Increasing practicality using student groups. Psychology in the Schools, 47, 842-858. https://doi.org/10.1002/pits.20508

Okilwa, N.S.A., \& Shelby, L. (2010). The effects of peer tutoring on academic performance of students with disabilities in grades 6 through 12: A synthesis of the literature. Remedial and Special Education, 31, 450- 463. https://doi.org/10.1177/0741932509355991

Sabag, N., \& Trotskovsky, E. (2016). An Examination of the Relationship between Instructional Strategies to Learning Styles Distance and Students' Achievements. International Journal of Engineering Education, 32(5A), 1903-1910.

Safe, A. (2008). New educational psychology. Furth press, Tehran, Duran publication.

Soloman, B.A., \& Felder, R.M. (2014). Index of Learning Styles Questionnaire (web version). Retrieved from http://www.engr.ncsu.edu/learningstyles/ilsweb.html

Tella, A., Tella, A., \& Adeniyi, O. (2009). Locus of control, interest in schooling, self-efficacy and academic achievement. Cypriot Journal of Educational Sciences, 4(3), 168-182.

Tuckman, B.W. (1999). Conducting Educational Research (5th ed.). Belmont, CA: Wadsworth Group.

Warn, T.S. (2009). Students' learning style and their academic achievement for Taxation course-A comparison study. In Proceedings of the 2nd International Conference of Teaching and Learning (ICTL 2009). INTI University College, Malaysia.

Zhang, L.F., \& Sternberg, R.J. (2005). A threefold model of intellectual styles. Educational Psychology Review, 17(1), 1-53. http://dx.doi.org/10.1007/s10648-005-1635-4

Zywno, M.S. (2003). A contribution to validation of score meaning for Felder-Soloman's Index of Learning Styles. Proceedings of the 2003 American Society for Engineering Education Annual Conference \& Exposition. 